\title{
Postawy społeczne wobec deforestacji lasów tropikalnych
}

\author{
Wojciech Trempała*, Sławomir Sadowski \\ Instytut Nauk Politycznych, Uniwersytet Kazimierza Wielkiego w Bydgoszczy \\ ul. Księcia Józefa Poniatowskiego 12, 85-667 Bydgoszcz \\ *wtrempala@wp.pl
}

\section{Streszczenie}

Artykuł prezentuje wyniki badań nad postawami człowieka wobec zjawiska niszczenia lasów tropikalnych. Pomiaru empirycznego dokonano w latach 2014-2015 na reprezentatywnej, liczącej 1000 osób, próbie mieszkańców województwa kujawsko-pomorskiego. Ankietowani zostali poproszeni o ustosunkowanie się do czterech stwierdzeń, które w swej treści wyrażają zgodę lub brak zgody na wyrąb lasów tropikalnych. Pod względem aksjologicznym i normatywnym stwierdzenia te zostały dopasowane do przyjętego w etyce środowiskowej podziału na stanowiska antropocentryczne i biocentryczne. Uzyskane wyniki wskazują, że zdecydowana większość respondentów odrzuca antropocentryzm indywidualistyczny, zgodnie z którym wycinka lasów tropikalnych może być uzasadniona dobrem i interesem poszczególnych jednostek. Jednocześnie wyrażają oni wysoką aprobatę dla stanowisk biocentrycznych, których treść zawiera sprzeciw wobec destrukcyjnej ingerencji człowieka w funkcjonowanie tropikalnej puszczy. Niemniej jednak, większość osób badanych dopuszcza możliwość wyrębu lasu tropikalnego jedynie wówczas, jeśli służy to dobru całego społeczeństwa i przyszłych pokoleń.

\section{Słowa kluczowe}

las, socjologa środowiskowa, postawy ekologiczne, antropocentryzm, biocentryzm

\section{Wprowadzenie}

Lasy spełniają wiele funkcji kształtujących środowisko życia na Ziemi. Regulują klimat i spływ wód, chronią gleby przed erozją wietrzną, zapobiegają lawinom i osuwiskom, stanowią naturalne źródło czystego powietrza oraz surowców stymulujących rozwój ekonomiczny gospodarek lokalnych, jak i gospodarki globalnej. Ponadto zaspakajają potrzeby duchowe, rekreacyjne czy też edukacyjne społeczeństwa determinując specyfikę, tembr życia i tożsamość kulturową społeczności, których aktywność życiowa skupia się wokół terenów leśnych (Dobrzańska 2010: 142-144; Sadowski, Trempała 2018: 184-196). Z jednej więc strony lasy stanowią niezwykle istotny element stymulujący funkcjonowanie całego ekosystemu naszej planety, z drugiej zaś wartość ważną przede wszystkim z punktu widzenia potrzeb ekonomicznych i kulturowych gatunku ludzkiego, których zaspokojenie wiąże się z antropogeniczną ingerencją prowadzącą nierzadko do zjawiska degradacji obszarów leśnych. Konstatacja ta stanowi inspirację do sformułowania głównego celu niniejszego artykułu. Jest nim - oparta na wynikach ilościowych 
badań empirycznych - analiza antropocentryzmu i biocentryzmu w postawach człowieka wobec wycinki lasów tropikalnych.

\section{Metodologia i problematyka badań}

Prezentowane przez autorów wyniki pomiarów postaw, stanowią nieopublikowany dotąd wycinek szerszego projektu empirycznego poświęconego badaniu antropocentrycznych i biocentrycznych przekonań ekologicznych społeczeństwa. Został on przeprowadzony w latach 2014-2015 na reprezentatywnej próbie 1000 mieszkańców województwa kujawsko-pomorskiego przy użyciu kwestionariusza ankiety. W ramach omawianej w niniejszym artykule części badania, respondenci zostali poproszeni o ustosunkowanie się do grupy 4 stwierdzeń, które w swej treści wyrażają zgodę lub brak zgody na wyrąb lasów tropikalnych. Pod względem aksjologicznym i normatywnym stwierdzenia te zostały dopasowane do przyjętego w etyce środowiskowej podziału na stanowiska antropocentryczne i biocentryczne.

Zastosowane kryteria konceptualizacji tychże stanowisk prezentuje Tabela 1 , zaś sformułowane w oparciu o te kryteria stwierdzenia, które wykorzystano do zmierzenia postaw osób badanych wobec wycinki lasów tropikalnych przedstawia Tabela 2.

Warto w tym miejscu nadmienić, że wprowadzenie dodatkowego podziału stanowiska antropocentrycznego na indywidualistyczny i socjocentryczny wynikało z potrzeby przeniesienia podziału stanowisk biocentrycznych pod kątem perspektywy indywidualistycznej i systemowej na stanowisko antropocentryczne w celu zapewnienia symetrycznego dla obu ujęć spektrum pomiaru i analizy treści. W tym celu wykorzystano wyodrębniony $\mathrm{m}$. in. przez Jerzego Szackiego, aksjologiczny model ujmowania opozycyjnych wobec siebie kategorii kolektywizmu i indywidualizmu. Zgodnie z nim, kolektywizm nakazuje prymat obowiązków wobec społeczeństwa jako całości, zaś indywidualizm ujmuje społeczeństwo jako środek ochrony praw jednostek jako jednostek, a nie członków zbiorowości (Jerzy Szacki za: Scheffs 2016: 66).

Zadaniem osób badanych było wyrażenie własnej opinii na temat stwierdzeń poprzez wybór jednego z pięciu wariantów odpowiedzi właściwych skali modelu likertowskiego. Przejawiana przez respondentów akceptacja dla perspektyw antropocentrycznych punktowana była najniższymi wartościami (odpowiednio 1 za "Zdecydowanie się zgadzam" i 2 za „Raczej się zgadzam”), zaś brak akceptacji najwyższymi (odpowiednio 4 za „Raczej się nie zgadzam” i 5 za „Zdecydowanie się nie zgadzam"). Z kolei do pomiaru stwierdzeń biocentrycznych użyto odwróconego systemu oceniania. We wszystkich przypadkach każdej odpowiedzi odzwierciedlającej brak opinii lub niezdecydowanie respondenta („Nie mam zdania”) przydzielano 3 punkty. W efekcie wskaźnikami nasilenia mierzonych postaw były przede wszystkim uśrednione wartości odpowiedzi respondentów. Im były one niższe, tym mocniej odzwierciedlały wyodrębnione przez autorów wariacje antropocentrycznych i anty-biocentrycznych modeli przekonań respondentów, a im wyższe, tym bardziej zdecydowanie umożliwiały typologizację poglądów osób badanych w kategoriach biocentryzmu indywidualistycznego, ekocentryzmu i anty-antropocentryzmu (Tabela 3).

Niezbędne w tym miejscu jest także postawienie pytania o to, dlaczego ankietowanych zapytano o ich stosunek do wycinki lasów tropikalnych, nie zaś o ingerencję ludzką w ekosystemy leśne bliższe miejscu zamieszkania osób badanych. Odpowiedź można uzasadnić w oparciu o co najmniej trzy argumenty.

Po pierwsze, powierzchnia lasów w Polsce systematycznie rośnie dziś zajmując prawie 30\% obszaru kraju, a „Krajowy program zwiększania lesistości", zakłada wzrost lesistości do 33\% u progu II połowy XXI wieku (Web-o1). Do końca roku 2015 a więc momentu, w którym ukończono proces zbierania materiału empirycznego poza sporem o przebieg Obwodnicy Augustowskiej trudno doszukać się głośnego 
Tab. 1. Przyjęte modele reprezentacji postaw respondentów wobec przyrody (źródło: opracowanie własne na podstawie: Naess 1973; Norton 1984; Taylor 1986; Bonenberg 1992; Piątek 1998; Tyburski 1998; Fiut 1999; Kortenkamp, Moore 2001; Ciążela 2009; Ganowicz-Bączyk 2009)

Modele postawy

człowieka wobec przyrody

\begin{tabular}{lll}
\hline $\begin{array}{l}\text { Antropocentryzm } \\
\text { indywidualistyczny }\end{array}$ & $\begin{array}{l}\text { Tylko człowiek posiada interesy. } \\
\text { Prymat realizacji interesów } \\
\text { indywidualnych nad społecznymi. }\end{array}$ & $\begin{array}{l}\text { Dobre jest takie działanie wobec przyrody, które sprzyja } \\
\text { interesom poszczególnych jednostek nawet kosztem } \\
\text { większości społecznej. }\end{array}$ \\
\hline $\begin{array}{l}\text { Antropocentryzm } \\
\text { socjocentryczny }\end{array}$ & $\begin{array}{l}\text { Tylko człowiek posiada interesy. } \\
\text { Prymat realizacji interesów } \\
\text { społecznych nad jednostkowymi. }\end{array}$ & $\begin{array}{l}\text { Dobre jest takie działanie wobec przyrody, które przyczynia } \\
\text { się do pomyślności obecnego społeczeństwa i przyszłych } \\
\text { pokoleń nawet kosztem interesu poszczególnych jednostek. }\end{array}$ \\
\hline $\begin{array}{l}\text { Biocentryzm } \\
\text { indywidualistyczny }\end{array}$ & $\begin{array}{l}\text { Każda istota żywa posiada swoje } \\
\text { interesy i wartości witalne, a więc } \\
\text { także prawo do ich realizacji. }\end{array}$ & $\begin{array}{l}\text { Dobra jest jedynie taka ingerencja człowieka w przyrodę, } \\
\text { która nie zagraża życiu jakichkolwiek istot. }\end{array}$ \\
\hline $\begin{array}{l}\text { Ekocentryzm (Holizm) } \\
\text { Każdy byt posiada swoje interesy } \\
\text { i wartości witalne, które są mniej } \\
\text { istotne niż dobro całego ekosystemu. }\end{array}$ & $\begin{array}{l}\text { Dobre jest takie działanie wobec przyrody, które przy } \\
\text { możliwie jak największym uwzględnieniu dobra } \\
\text { pojech istot, przede wszystkim nie będzie zagrażało }\end{array}$ \\
& & harmonijnemu funkcjonowaniu całego ekosystemu.
\end{tabular}

Tab. 2. Przyjęte modele reprezentacji postaw respondentów wobec wycinki lasów tropikalnych (źródło: opracowanie własne)

\begin{tabular}{ll}
\hline \multicolumn{1}{c}{ Orientacja } & \multicolumn{1}{c}{ Stwierdzenie } \\
\hline Antropocentryzm indywidualistyczny & $\begin{array}{l}\text { Wyrąb lasu tropikalnego może być uzasadniony nawet wówczas, jeśli służy to } \\
\text { interesom pojedynczego człowieka, nawet wtedy gdy niszczone są dzikie gatunki } \\
\text { zwierząt i roślin oraz lokalne ekosystemy }\end{array}$ \\
\hline Antropocentryzm socjocentryczny & $\begin{array}{l}\text { Wyrąb lasu tropikalnego może być uzasadniony tylko wówczas, jeśli służy to } \\
\text { interesom całego społeczeństwa i przyszłych pokoleń (całej ludzkości), a nie } \\
\text { interesom poszczególnych jednostek. }\end{array}$ \\
\hline Biocentryzm indywidualistyczny & $\begin{array}{l}\text { Ludzie nie mają prawa niszczyć lasów tropikalnych w celu realizacji swoich interesów, } \\
\text { jeśli groziłoby to bezpieczeństwu i dobru jakiegokolwiek gatunku bądź aktualnie } \\
\text { występujących tam istot żywych. }\end{array}$ \\
\hline Ekocentryzm & $\begin{array}{l}\text { Ludzie nie mają prawa niszczyć lasów tropikalnych w celu realizacji swoich interesów, } \\
\text { jeśli groziłoby to bezpieczeństwu i dobru globalnego ekosystemu. }\end{array}$
\end{tabular}

Tab. 3. Przyjęta przez autorów typologia stopni nasilenia przekonań respondentów na temat wyrębu lasów tropikalnych (źródło: opracowanie własne)

\begin{tabular}{lc}
\hline \multicolumn{1}{c}{ Typ przekonań } & Punktacja \\
\hline Silny biocentryzm indywidualistyczny/holizm & od 4,5 do 5,0 \\
\hline Umiarkowany biocentryzm indywidualistyczny/holizm & od 3,5 do 4,49 \\
\hline Ambiwalencja/obojętność ekologiczna & od 2,5 do 3,49 \\
\hline Umiarkowany antropocentryzm indywidyualistyczny/socjocentryczny & od 1,5 do 2,49 \\
\hline Silny antropocentryzm indywidualistyczny/socjocentryczny & od 1 do 1,49 \\
\hline
\end{tabular}


medialnie, ogólnopolskiego konfliktu społeczno-politycznego skoncentrowanego wokół lasu jako kategorii aksjologicznej. Taki pojawił się dopiero w szerszej świadomości Polaków w kontekście decyzji wydanej w marcu 2016 roku przez Ministerstwo Środowiska o zwiększeniu wycinki drzewostanu w Puszczy Białowieskiej w celu - jak uzasadniało to wówczas ministerstwo - ratowania tegoż ekosystemu przed niszczycielską plagą kornika drukarza ${ }^{1}$.

1 Warto dodać, że choć spór ten zaistniał już po przeprowadzeniu prezentowanych badań, to jest o tyle istotny z punktu widzenia niniejszego artykułu, że ujawnił antropocentryczne i biocentryczne motywacje społeczeństwa polskiego w działaniach na rzecz ochrony lasów oraz całego środowiska przyrodniczego - legitymując tym sposobem zasadność przedstawianego tu projektu badawczego. Kwintesencję tych motywacji - zdaniem autorów stanowi opublikowana na stronach Wirtualnej Polski w maju 2016 roku wymiana opinii na temat podejścia do ochrony Puszczy Białowieskiej przeprowadzona pomiędzy dwoma dziennikarzami, to jest znanym działaczem na rzecz ochrony środowiska, autorem wielu popularnonaukowych książek przyrodniczych i związanym z "Gazetą Wyborczą" Adamem Wajrakiem a publicystą tygodnika „Do Rzeczy”, filozofem i historykiem Marcinem Makowskim.

Adam Wajrak swymi wypowiedziami reprezentował środowiska opowiadające się za brakiem ingerencji w naturalne procesy rządzące wspominanym ekosystem leśnym, nawet jeśli wiąże się to z wieloletnimi, destrukcyjnymi dla obecnego stanu Puszczy Białowieskiej procesami sukcesji ekologicznej. Swoje stanowisko, które autorzy kwalifikują jako biocentryczne, uzasadniał słowami: Przyroda - ludzie czuja to instynktownie - to jest taka rzecz, która nas jednoczy, z której możemy być dumni. To jest mój taki bardzo nowoczesny patriotyzm, który nie jest skierowany przeciwko komuś. Jest tu $i$ teraz. Losem Puszczy Białowieskiej interesuja się lewacy $i$ prawacy, centrowi, katolicy, ultrakatoliccy, antyklerykałowie itd. Po czym w dalszej części wywiadu dodał: Polacy chca, kurna, zapuszczonej puszczy. Koniec kropka. Żadnych upraw, żadnego sadzenia, żadnego ratowania przed kornikiem. Symbolem naszego narodu jest dzika puszcza. Kto tego nie rozumie, musi przegrać (Web - 02).

W odpowiedzi na słowa Wajraka Marcin Makowski przedstawił argumentację na rzecz ochrony Puszczy Białowieskiej, która bliższa jest środo-
Po drugie, wycinka lasów tropikalnych, stanowi jeden - obok globalnych zmian klimatu, dziury ozonowej i zanieczyszczeń powietrza - z najczęściej eksponowanych, globalnych problemów ekologicznych. Wynika to między innymi z faktu, iż tereny dżungli zamieszkuje od 50 do 70\% wszystkich gatunków flory i fauny. Na wybranych obszarach puszcz okołorównikowych rośnie średnio 200 do 300 gatunków drzew, zaś ich niszczenie prowadzi do intensyfikacji globalnych zmian klimatu (Dobrzańska 2010: 149). W ostatnich latach - w tym także w okresie prowadzenia badań - duże zainteresowanie środków masowego przekazu i organizacji ekologicznych budziła kwestia niszczenia (karczowania, podpalania) lasów na obszarze Indonezji pod plantacje palmowe służące do produkcji oleju. Media, organizacje ekologiczne oraz eksperci zwracają uwagę na spowodowaną tymi działaniami emisję dwutlenku węgla do atmosfery czy zagrożenie dla życia ludzi i zwierząt. Powtarzające się w okresie prowadzenia badań obrazy medialne duszących się osób, ratowanych ze smogu orangutanów czy słoni budziły silne emocje, nawet jeśli polscy odbiorcy nie do końca byli w stanie w tym przypadku dostrzec - pozornie odroczone w czasie - zagrożenia globalne ważne z punktu widzenia także nich samych.

Po trzecie, inspiracją dla pomysłu zmierzenia stosunku społeczeństwa wobec wycinki lasów tropikalnych była opublikowana przez Zdzisławę Piątek w książce „Etyka środowiskowa - nowe spojrzenie na miejsce

wiskom przekonanym o tym, że tylko człowiek za pośrednictwem wiedzy i technologii jest w stanie uratować ją przed degradacją spowodowaną plagą kornika drukarza. Swe wyraźnie zabarwione antropocentrycznym podejściem do ochrony przyrody przekonania wyraził słowami, że: „(...) Puszcza Biatowieska poradzi sobie sama, ale będzie wygladać inaczej niż dotychczas. W wielu miejscach zdominuje ja jeden gatunek (np. zaborczy grab), a więc zubożeje. Co więcej, w dalszej części swego wywodu dodał,: Argumentacja Wajraka w dużej mierze jest charakterystyczna dla osób, które nie potrafia sie pogodzić z prymatem człowieka nad przyroda (Web-03). 
człowieka w przyrodzie" krytyka antropocentrycznej wersji etyki ochrony środowiska Johna Passmore'a. Jak pisała wspomniana filozofka: „Wbrew Passmorowi, sądzę, że antropocentryczna wersja etyki ochrony środowiska, czyli zastosowanie etyki tradycyjnej do rozwiązywania problemów środowiskowych, ma tak wiele słabych stron, że jej dalsze stosowanie mogłoby jedynie pogłębić narastający kryzys środowiskowy". Po czym skonstatowała, iż: „Pozaludzkie istoty żywe i naturalne ekosystemy mają w obrębie tej etyki wartości czysto instrumentalne i ani ich nie cenimy, ani nie ochraniamy dla nich samych. Wartość nadrzędną stanowią fundamentalne ludzkie wartości: wolność indywidualna i dobro własne człowieka. Jeżeli zatem uznamy, że dla dobra ludzi żyjących w Ameryce Południowej należy wyciąć dżunglę nad Amazonką, to antropocentrycznie zorientowana etyka pozwala to uczynić i na tym polega jej słabość" (Piątek 1998: 156).

Przedstawiona argumentacja Zdzisławy Piątek jest interesująca i w dużej mierze trafna z punktu widzenia refleksji filozoficzno-etycznej na temat relacji człowieka z przyrodą. Wydaje się jednak mniej zasadna na gruncie wnioskowania socjologicznego. Pomija bowiem właściwą człowiekowi złożoność, ambiwalencję czy też niespójność postaw, których poszczególne komponenty w zróżnicowanym stopniu mogą decydować o ludzkich zachowaniach (np. podjęciu protestu czy też różnie motywowanemu aktywnemu poparciu wobec wycinki lasów tropikalnych) ${ }^{2}$.

Tym samym zaprezentowane w dotychczasowym wywodzie argumenty skłoniły autorów do postawienia następujących pytań badawczych:

1. Jak kształtują się przekonania respondentów na temat wyrębu lasów tropikalnych?

1a. Czy dominuje tu perspektywa antropocentryczna czy biocentryczna?

2 Taki protest może być chociażby wyrażony poprzez rezygnację, zaś poparcie poprzez brak rezygnacji z zakupu produktów powstałych przy użyciu oleju palmowego. 1b. Czy dominuje tu perspektywa indywidualistyczna czy systemowa/ kolektywistyczna?

2. Czy przekonania respondentów na temat wyrębu lasów tropikalnych różnicują się ze względu na płeć, wiek, wykształcenie, miejsce zamieszkania i poglądy polityczne? A jeśli tak, to w jakim zakresie?

W oparciu o szereg dotychczasowych ustalonych faktów i wyników badań dotyczących świadomości ekologicznej, autorzy podjęli decyzję o potrzebie przetestowania trzech następujących hipotez:

H1. Spośród wszystkich ujętych w badaniu stanowisk, najniższym poziomem akceptacji wśród respondentów cechuje się podejście antropocentryczno-indywidualistyczne.

Uzasadnienie: Założenie to autorzy przyjęli w oparciu o analizę wyników badań empirycznych nad świadomością ekologiczną społeczeństwa polskiego, które wskazują na oscylującą wokół $75 \%$ zgodę respondentów $\mathrm{z}$ opinią, iż w planowaniu dalszego rozwoju kraju należy w równym stopniu brać pod uwagę kwestie społeczne, gospodarcze i środowiskowe (Bortłomiuk 2009: 10) a ochrona środowiska może wpłynąć pozytywnie na wzrost gospodarczy kraju (Web-o4).

H2. Wśród respondentów nieznacznie dominuje perspektywa biocentryczna nad antropocentryczną.

Uzasadnienie: Hipoteza ta opiera się na niemal identycznych przesłankach jak hipoteza 1. Rosnące w życiu społecznym znaczenie zagrożeń ekologicznych i wiedzy na temat wpływu działalności człowieka na środowisko przyrodnicze z dużym prawdopodobieństwem powinno przełożyć się na preferowanie tych wariantów odpowiedzi, które w sposób najbardziej wyrazisty uwzględniają dobro przyrody w systemie postaw człowieka.

H3. Poglądy polityczne, miejsce zamieszkania, wiek, płeć oraz wykształcenie stanowią zbiór zmiennych najsilniej różnicujących przekonania respondentów na temat ujętych w badaniu postaw wobec środowiska przyrodniczego. 
Uzasadnienie: Przyjęte przez autorów przypuszczenia dotyczące zmiennych socjodemograficznych, które najsilniej różnicują przekonania ekologiczne badanych zostały sformułowane w oparciu o analizę wyników z dotychczasowych anglosaskich i polskich badań nad świadomością ekologiczną (Dunlap, Catton 1979; McMillan, Hoban, Clifford, Brant, 1997; Dunlap, Van Liere, Mertig, Jones, 2000; Burger, 2005; Aminrad, Zakaria, Hadi, 2011). Wskazują one, że osoby o lewicowo-liberalnych poglądach politycznych, młodzież i młodzi dorośli, mieszkańcy miast, kobiety oraz osoby legitymujące się wyższym wykształceniem częściej cechują się wrażliwością ekologiczną niż pozostałe grupy.

\section{Przekonania respondentów na temat wyrębu lasów tropikalnych}

Uzyskane rezultaty potwierdziły większość założeń badawczych zaprezentowanych w części metodologicznej niniejszego artykułu. Respondenci w zdecydowanej większości odrzucili stanowisko antropocentryzmu indywidualistycznego na rzecz antropocentryzmu socjocentrycznego, zaś ich przekonania na temat wyrębu lasów tropikalnych charakteryzują się ponadto przewagą perspektywy biocentrycznej i antyantropocentrycznej nad antropocentryczną. Warto w tym miejscu również podkreślić, że szczególnie duży poziom akceptacji został wyrażony przez ankietowanych wobec obu zaproponowanych im stanowisk systemowych, a zwłaszcza ujęcia ekocentrycznego, które zyskało najwyższe, bo liczące blisko $72 \%$ poparcie osób badanych. Co więcej, stwierdzenie zawierające argumentację ekocentryczną otrzymało także najwięcej głosów zdecydowanie aprobujących jego treść oraz najmniej głosów przeciwnych (Tabela 4).

Uśredniony wynik w całej próbie osób badanych wyniósł $M=3,91$, co oznacza, że według przyjętej - i zaprezentowanej w części metodologicznej - typologii stopni nasilenia preferencji antropocentrycznych oraz biocentrycznych (Tabela 3 ) poziom akceptacji dla omawianego stwierdzenia kształtuje się na poziomie umiarkowanego biocentryzmu. Częściej stanowisko ekocentryczne było popierane łącznie ${ }^{3}$ przez osoby o lewicowych poglądach politycznych (zdecydowanie lewicowe: 83,05\%; umiarkowanie lewicowe: $78,68 \%$; apolityczne: $76,61 \%$; umiarkowanie prawicowe: $67,86 \%$; zdecydowanie prawicowe: $\left.51,48 \% ; r_{\mathrm{s}}=-0,15, \mathrm{p}<\mathrm{O}, \mathrm{O} 1^{4}\right)$, osoby legitymujące się wyższymi poziomami wykształcenia formalnego (podstawowe i zasadnicze zawodowe: $65,2 \%$; średnie: $77,65 \%$; wyższe: $\left.79,74 \% ; r_{\mathrm{s}}=0,15, \mathrm{p}<0,01\right)$, mieszkańców miast (miasta - zdecydowanie się zgadzam: $43 \%$; raczej się zgadzam: 30,35\%; wieś - zdecydowanie się zgadzam: 22,6\%; raczej się zgadzam: 46,93\%; $\left.r_{\mathrm{s}}=0,14, \mathrm{p}<0,01\right)$ oraz mężczyzn (mężczyźni:75,44\%; kobiety: 67,91\%; $\left.r_{\mathrm{s}}=0,09, \mathrm{p}<0,01\right)$.

Drugim w kolejności, najchętniej aprobowanym przez respondentów - w kontekście omawianego problemu, czy też dylematu z zakresu etyki środowiskowej - stanowiskiem był biocentryzm indywidualistyczny. Przekonanie, że gatunek ludzki nie ma prawa niszczyć lasów tropikalnych w celu realizacji swoich interesów, jeśli tylko groziłoby to bezpieczeństwu i dobru jakiegokolwiek gatunku bądź aktualnie występujących tam istot żywych okazało się być bliskie łącznie 66,7\% ankietowanym (zdecydowanie się zgadzam: 27,8\%; raczej się zgadam: $38,9 \%$ ).

Średni wynik wszystkich odpowiedzi, wynoszący $M=3,77$ (Tabela 5), podobnie jak w przypadku perspektywy ekocentrycznej, sytuuje się na poziomie umiarkowanego biocentryzmu. Ponadto tak jak i w podejściu ekocentrycznym do kwestii wycinki lasów tropikalnych, tak i w przypadku biocentryzmu indywidualistycznego najsilniej było ono zgodne z przekonaniami osób o lewicowych poglądach politycznych

3 Określenie łącznie oznacza, że autorzy zsumowali na potrzeby analizy odpowiedzi zdecydowanie się zgadzam i raczej się zgadzam.

4 Do zmierzenia korelacji pomiędzy poszczególnymi zmiennymi użyto testu współczynnika korelacji rang Spearmana dostępnego w oprogramowaniu komputerowym Statistica. 
Tab. 4. Ekocentryzm - uśredniony wynik oraz procentowe rozkłady odpowiedzi respondentów na temat wyrębu lasu tropikalnego (źródło: opracowanie własne)

\begin{tabular}{lccccccc}
\hline \multicolumn{1}{c}{ Stwierdzenie } & Orientacja & $\mathrm{M}^{\mathrm{a}}$ & ZT & RT & NZD & RN & ZN \\
\hline $\begin{array}{l}\text { Ludzie nie mają prawa niszczyć lasów } \\
\begin{array}{l}\text { tropikalnych w celu realizacji swoich interesów, } \\
\text { jeśli groziłoby to bezpieczeństwu i dobru }\end{array}\end{array}$ & Ekocentryzm & 3,91 & 34,7 & 37,1 & 17,2 & 7,4 & 3,6 \\
globalnego ekosystemu. & & & & & & & \\
\hline
\end{tabular}

${ }^{a} \mathrm{M}$ - średnia; ZT - zdecydowanie się zgadzam; RT - raczej się zgadzam; NZD - nie mam zdania; RN - raczej się nie zgadzam;

ZN - zdecydowanie się nie zgadzam

Tab. 5. Biocentryzm indywidualistyczny - uśredniony wynik oraz procentowe rozkłady odpowiedzi respondentów na temat wyrębu lasu tropikalnego (źródło: opracowanie własne)

\begin{tabular}{lccccccc}
\hline \multicolumn{1}{c}{ Stwierdzenie } & Orientacja & M & ZT & RT & NZD & RN & ZN \\
\hline $\begin{array}{l}\text { Ludzie nie mają prawa niszczyć lasów } \\
\text { tropikalnych w celu realizacji swoich interesów, } \\
\text { jeśli groziłoby to bezpieczeństwu i dobru } \\
\text { jakiegokolwiek gatunku bądź aktualnie } \\
\text { występujących tam istot żywych. }\end{array}$ & $\begin{array}{c}\text { Biocentryzm } \\
\text { indywidualistyczny }\end{array}$ & 3,77 & 27,8 & 38,9 & 19,4 & 10,2 & 3,7 \\
\hline
\end{tabular}

Tab. 6. Antropocentryzm socjocentryczny- uśredniony wynik oraz procentowe rozkłady odpowiedzi respondentów na temat wyrębu lasu tropikalnego (źródło: opracowanie własne)

\begin{tabular}{|c|c|c|c|c|c|c|c|}
\hline Stwierdzenie & Orientacja & $M$ & $\mathrm{ZT}$ & RT & NZD & $\mathrm{RN}$ & ZN \\
\hline $\begin{array}{l}\text { Wyrąb lasu tropikalnego może być } \\
\text { uzasadniony tylko wówczas, jeśli służy to } \\
\text { interesom całego społeczeństwa i przyszłych } \\
\text { pokoleń (całej ludzkości), a nie interesom } \\
\text { poszczególnych jednostek. }\end{array}$ & $\begin{array}{l}\text { Antropocentryzm } \\
\text { socjocentryczny }\end{array}$ & 2,40 & 23,4 & 41,8 & 13,7 & 13,6 & 7,5 \\
\hline
\end{tabular}

(zdecydowanie lewicowe: $76,28 \%$; umiarkowanie lewicowe: $75,83 \%$; apolityczne: $74 \%$; umiarkowanie prawicowe: $53,58 \%$; zdecydowanie prawicowe: $\left.54,42 \% ; r_{\mathrm{s}}=-0,16, \mathrm{p}<0,01\right)$, mężczyzn (mężczyźni: 71,38\%; kobiety: $\left.61,7 \% ; r_{\mathrm{s}}=0,13, \mathrm{p}<\mathrm{0}, 01\right)$, mieszkańców miast (miasto - zdecydowanie sie zgadzam: $34,9 \%$; raczej się zgadzam; 32,2\%; wieś - zdecydowanie się zgadzam: 17,44\%; raczej się zgadzam: 48,65\%; $\left.r_{\mathrm{s}}=0,11, \mathrm{p}<\mathrm{0}, 01\right)$, a zgodność ta okazała się być szczególnie wysoka wśród osób legitymujących się ukończeniem szkoły średniej oraz studiów na poziomie magisterskim (podstawowe i zasadnicze zawodowe: $61,72 \%$; średnie: $73,17 \%$; wyższe I stopnia: $52 \%$; wyższe II stopnia $\left.72,5 \% ; r_{\mathrm{s}}=0,1, \mathrm{p}<0,01\right)$.

Wysoki poziom akceptacji dla stanowisk biocentrycznych nie oznacza jednocześnie zupełnego odrzucenia perspektywy antropocentrycznej przez respondentów. Świadczy o tym wyrażony przez nich wysoki poziom poparcia dla antropocentryzmu socjocentrycznego. Łącznie, ponad $65 \%$ ankietowanych uznało za zgodne $\mathrm{z}$ ich przekonaniami stwierdzenie wskazujące na zasadność wyrębu lasu tropikalnego, jeśli miałoby to służyć interesom całego społeczeństwa i przyszłych pokoleń (całej ludzkości), a nie interesom poszczególnych jednostek (Tabela 6).

Według przyjętej typologii stopni nasilenia postaw antropocentrycznych i biocentrycznych, średni - wynoszący $M=2,4$ - wynik odpowiedzi dla całej próby osób badanych mieści się $\mathrm{w}$ przedziale umiarkowanego antropocentryzmu. Spośród wszystkich 
ujętych w analizie zmiennych socjo-demograficznych, jedynie wiek $\left(r_{\mathrm{s}}=-0,13, \mathrm{p}<0,01\right)$ i miejsce zamieszkania $\left(r_{\mathrm{s}}=-0,09, \mathrm{p}<0,01\right)$ w sposób istotny statystycznie różnicowały opinie respondentów.

Stanowisko antropocentryzmu socjocentrycznego okazało się szczególnie atrakcyjne dla osób powyżej 45 roku życia (45-54 lat: 70,06\%; 55-64 lat: 79,75\%; 65 lat i więcej: $69 \%)$. Nieco mniej chętnie było ono popierane przez młodzież (16-18 lat: 65,3\%; 1924 lat: $62,93 \%)$ i osoby w wieku od 35 do 44 roku życia $(65,6 \%)$. Na najniższy poziom akceptacji dla antropocentryzmu socjocentrycznego wskazały natomiast osoby liczące od 25 do 34 lat (48\%). Z kolei różnice w odpowiedziach mieszkańców miast i wsi są najbardziej widoczne porównując procentowy stosunek odpowiedzi zdecydowanie oraz raczej akceptujących omawiane stwierdzenie w obu grupach. Mianowicie respondenci zamieszkujący obszary miejskie (zdecydowanie się zgadzam: 30,35\%; raczej się zgadzam: 34,57\%) częściej byli skłonni wyrażać zdecydowane poparcie dla antropocentryzmu socjocentrycznego, podczas gdy przeważająca większość mieszkańców terenów wiejskich wybrała odpowiedź „raczej się zgadzam” (zdecydowanie się zgadzam: 13,26\%; raczej się zgadzam: 52,33\%).

Jak wspomniano już we wstępie prezentowanej analizy, największy sprzeciw ankietowani przejawiali wobec twierdzenia reprezentującego perspektywę antropocentryczno-indywidualistyczną. Średni wynik odpowiedzi dla całej próby z populacji ukształtował się na poziomie umiarkowanego biocentryzmu $(M=3,77)$. Łącznie, aż $67 \%$ osób zanegowało zasadność wyrębu lasu tropikalnego, któremu towarzyszy niszczenie dzikich gatunków zwierząt i roślin, gdyby miałoby to służyć jedynie interesom pojedynczego człowieka. Swój pozytywny stosunek wyraziło w tym przypadku 16,7\% badanych (Tabela 7).

Poziom dezaprobaty wobec stanowiska antropocentryczno-indywidualistycznego rósł wraz z wykształceniem osób badanych (rysunek 1), ponadto wysokie wartości osiągał przede wszystkim wśród osób deklarujących lewicowe preferencje polityczne (zdecydowanie lewicowe: 66,9\%; umiarkowanie lewicowe: $76,31 \%$ ) oraz mieszkańców miast (72,35\%). Rzadziej był natomiast wyrażany przez osoby o poglądach prawicowych (umiarkowanie prawicowe: $65,88 \%$; zdecydowanie prawicowe: $53,68 \%$ ) oraz wśród respondentów zamieszkujących tereny wiejskie $(59,22 \%)$. Wykształcenie $\left(r_{\mathrm{s}}=\right.$ $0,27, \mathrm{p}<0,01)$, poglądy polityczne $\left(r_{\mathrm{s}}=-0,12\right.$, $\mathrm{p}<0,01)$ i miejsce zamieszkania $\left(r_{\mathrm{s}}=0,19\right.$, $\mathrm{p}<\mathrm{o}, \mathrm{o1})$ to jedyne $\mathrm{w}$ przypadku omawianego stwierdzenia zmienne socjo-demograficzne, które w sposób istotny statystycznie różnicowały odpowiedzi respondentów.

Tab. 7. Antropocentryzm indywidualistyczny - uśredniony wynik oraz procentowe rozkłady odpowiedzi respondentów na temat wyrębu lasu tropikalnego (źródło: opracowanie własne)

\begin{tabular}{|c|c|c|c|c|c|c|c|}
\hline Stwierdzenie & Orientacja & $\mathrm{M}$ & ZT & RT & NZD & RN & ZN \\
\hline $\begin{array}{l}\text { Wyrąb lasu tropikalnego może być } \\
\text { uzasadniony nawet wówczas, jeśli służy } \\
\text { to interesom pojedynczego człowieka, } \\
\text { nawet wtedy gdy niszczone są dzikie } \\
\text { gatunki zwierząt i roślin oraz lokalne } \\
\text { ekosystemy. }\end{array}$ & $\begin{array}{l}\text { Antropocentryzm } \\
\text { indywidualistyczny }\end{array}$ & 3,77 & 4,3 & 12,4 & 16,3 & 35,6 & 31,4 \\
\hline
\end{tabular}




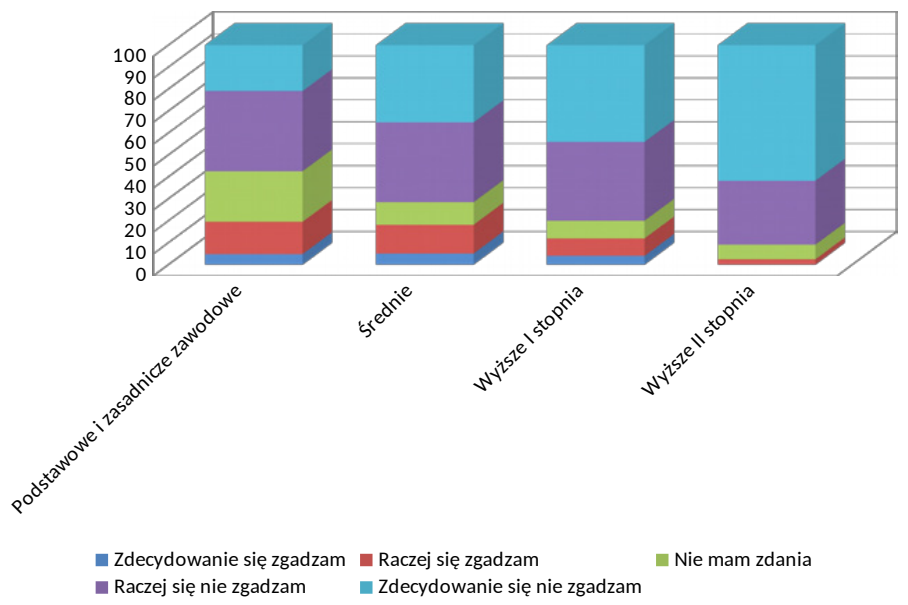

Rysunek 1. Procentowy rozkład odpowiedzi respondentów a ich wykształcenie

\section{Wnioski i dyskusja}

Przeprowadzona w niniejszym artykule analiza wyników badań na temat - rozpatrywanych w kategoriach antropocentryzmu i biocentryzmu - postaw społeczeństwa wobec niszczenia lasów tropikalnych potwierdziła większość założeń formułowanych na etapie projektowania procesu badawczego.

Po pierwsze, ankietowani w zdecydowanej większości odrzucili stanowisko antropocentryzmu indywidualistycznego kwestionując zasadność wyrębu lasów potrzebami poszczególnych jednostek.

Po drugie, według przyjętych kryteriów analizy, w opiniach respondentów na temat wszystkich czterech stwierdzeń, uwidacznia się przewaga poziomu nasilenia postaw biocentrycznych nad antropocentrycznymi. Nie oznacza to jednak, że osoby badane w zdecydowany sposób odrzucają perspektywę antropocentryczną w swoim stosunku do przedstawionego im dylematu etycznego. Świadczy o tym ich wysokie poparcie dla stanowiska antropocentryzmu socjocentrycznego, które dopuszcza możliwość wyrębu lasów tropikalnych tylko wówczas, jeśli służy to interesom całego społeczeństwa i przyszłych pokoleń (całej ludzkości), a nie interesom poszczególnych jednostek.

Po trzecie, założenia dotyczące zmiennych socjo-demograficznych najsilniej różnicujących przekonania respondentów na temat ujętych w badaniu postaw wobec wyrębu lasu tropikalnego - w dużej mierze potwierdziły się $\mathrm{w}$ przypadku obu stanowisk biocentrycznych. Najchętniej popierały je osoby deklarujace lewicowe preferencje polityczne, legitymujące się wyższym wykształceniem formalnym oraz mieszkańcy miast. Nie stwierdzono natomiast istotnych korelacji pomiędzy wiekiem a przekonaniami badanych. Za zaskakujący w świetle dotychczasowych badań nad świadomością ekologiczną należy uznać wyższy poziom stopni nasilenia postaw biocentrycznych wśród mężczyzn niż wśród kobiet.

Antropocentryzm indywidualistyczny najbliższy był z kolei preferencjom osób o prawicowych poglądach politycznych, respondentom legitymującym się niższymi szczeblami wykształcenia formalnego oraz mieszkańcom terenów wiejskich. Najmniejszą liczbę istotnych statystycznie zależności zachodzących pomiędzy cechami socjodemograficznymi badanych a zmienną objaśnianą zdiagnozowano w odniesieniu do antropocentryzmu socjocentrycznego. Największy poziom akceptacji wobec tego stanowiska wyraziły osoby powyżej 45 roku życia i młodzież, a najniższy ankietowani w wieku od 25 do 34 roku życia. Perspektywa ta okazała się być także nieco bardziej 
zgodna z opiniami mieszkańców wsi niż miast.

Niezależnie od stwierdzonych korelacji należy jednak stwierdzić, że poziom poparcia lub jego brak dla poszczególnych stwierdzeń kształtował się w każdym przypadku na zbliżonym, stosunkowo wysokim poziomie. Stanowiska biocentryczne i antropocentryzm socjocentryczny zyskały akceptację w przedziale od 65 do niemal $72 \%$, zaś antropocentryzm indywidualistyczny został zakwestionowany przez $67 \%$ ankietowanych. W całej badanej zbiorowości zdiagnozowano skłonność do myślenia o relacjach człowieka z przyrodą w kategoriach dobra większych całości, takich jak ekosystem, całe społeczeństwo, przyszłe pokolenia oraz dobra poszczególnych gatunków flory i fauny, zaś w znikomym stopniu w kategoriach interesu jednostek ludzkich. Tym samym uzyskane zależności należy traktować przede wszystkim jako wskaźnik tendencji występujących w przekonaniach poszczególnych grup osób badanych, nie zaś jako kryterium ich podziałów na te charakteryzujące się wysoką i niską wrażliwością ekologiczną.

W podsumowaniu niniejszego artykułu należy stwierdzić, że w kontekście zaprezentowanych w nim wyników jeszcze większego znaczenia badawczego nabierają przywołane w części metodologicznej spostrzeżenia Zdzisławy Piątek, zgodnie z którymi etyka antropocentryczna dopuszcza niszczenie lasów tropikalnych zawsze wtedy, gdy ktoś po prostu uzna, że służy to dobru określonej społeczności, np. żyjącej wokół terenów objętych wycinką. Diagnoza wskazująca na łączne występowanie perspektyw biocentrycznych i antropocentryzmu socjocentrycznego $\mathrm{w}$ przekonaniach respondentów wobec badanego zagadnienia nie wystarcza jednak, aby odpowiedzieć na pytanie o to, która z nich okaże się najmocniej wpływać na zachowanie ankietowanych w sytuacji wyraźnego, bezpośrednio odczuwanego konfliktu pomiędzy interesem człowieka a dobrem przyrody (lasu tropikalnego). Trudno bowiem dokładnie stwierdzić, co ankietowani rozumieli przez pojęcia dobra całego społeczeństwa, przyszłych pokoleń, ekosystemu czy poszczególnych istot. Jakie są dopuszczalne przez nich granice poszanowania lub braku poszanowania tego dobra? Niemniej jednak rezultaty przedstawionego projektu badawczego wytyczają drogę kontynuacji badań nad antropocentryzmem i biocentryzmem w postawach społeczeństwa. Wskazują bowiem na potrzebę uzupełnienia danych ilościowych o dane jakościowe, a wiedzę na temat przekonań o badania eksperymentalne, które łącznie umożliwią lepszą identyfikacje zależności zachodzących nie tylko pomiędzy poszczególnymi komponentami postaw ekologicznych, ale przede wszystkim pomiędzy postawami a zachowaniem ekologicznym.

\section{Bibliografia}

Aminrad Z., Zakaria S.Z.B.S, Hadi A.S., 2011, Influence of Age and Level of Education on Environmental Awarness and Attitude: Case Study on Iranian Students in Malaysian Universities, The Social Sciences, Vol 6. Issue 1, 15-19

Bołtromiuk A., 2009, Świadomość ekologiczna Polaków - zrównoważony rozwój. Raport z badań 2009, Instytut na Rzecz Ekorozwoju , Warszawa. Bonenberg M., 1992, Etyka środowiskowa. Założenia i kierunki, UJ, Kraków.

Burger T., 2005, Świadomość ekologiczna społeczeństwa polskiego, Instytut Gospodarki Przestrzennej i Mieszkalnictwa, Warszawa.

Ciążela H., 2009, Czy ekologia demokratyczna musi być antropocentryczna? Wokót pogląów Luca Ferry'ego, Problemy Ekorozwoju, vol. 4, no. 2, 89-94 Dobrzańska B.M., 2010, Zagrożenie lasów, w: Dobrzańska B., Dobrzański G., Kiełczewski D., "Ochrona środowiska przyrodniczego", PWN, Warszawa, 142-157.

Dunlap R.E., Catton W.R., 1979, Environmental sociology, Annual Review of Sociology, vol. 5. 243-273.

Dunlap R.E., Van Liere K.D., Mertig A., Jones R.E., 2000, New Trends in Measuring Environmental Attitudes: Measuring Endorsement of The New Ecological Paradigm: A Revised NEP Scale, Journal of Social Issues, vol. 56. no 3, 425-442.

Fiut I. S., 1999, ECOetyki - kierunki rozwoju aksjologii przyjaznej środowisku, Abrys, Kraków. 
Ganowicz-Bączyk A., 2009, Spór o etykę środowiskową, WAM, Kraków

Kortenkamp K.V., Moore C.F., 2001, Ecocentrism and Anthropocentrism: Moral Reasoning About Ecological Commons Dilemmas, Journal of Environmental Psychology, vol. 21, issue 3, 261-272.

Mcmillan M., Hoban T.J., Clifford W.B., Brant M.R., 1997, Social and demographic influences on environmental attitudes, Southern Rural Sociology, vol. 13. no. 1, 89-107.

Naess A., 1973, The shallow and the deep, long-range ecology movement. A summary, Inquiry: An Interdisciplinary Journal of Philosophy, Vol. 16, Issue 1-4, 95-100.

Norton B.G., 1984, Environmental ethics and weak anthropocentrism, Environmental Ethics , vol. 6, Issue 2, 131-148.

Piątek Z., 1998, Etyka środowiskowa. Nowe spojrzenie na miejsce człowieka w przyrodzie, Księgarnia Akademicka, Kraków.

Sadowski S., Trempała W., 2018, Nowe formy turystyki w Borach Tucholskich, w: Jalinik M, Bakiera S., "Turystyka na obszarach przyrodniczo-cennych", Zamiejscowy Wydział Leśny Politechniki Białostockiej w Hajnówce, 184-196.

Scheffs Ł., Kolektywizm i indywidualizm. Zachowania wyborcze w latach 2001-2011, UAM, Poznań 2016.
Taylor P., 1986, Respect for nature: A Theory of Environmental Ethics, Princeton University Press, New Jersey.

Tyburski W., 1998, Główne kierunki i zasady etyki środowiskowej, w: Papuziński A., „Wprowadzenie do filozoficznych problemów ekologii”, WSP, Bydgoszcz, 97-132

(Web-o1) Łukasz Sawa, Polskie lasy, http://www.olsztyn.lasy.gov.pl/polskie-lasy\#.WxZ9pFUzaM8,dostęp: 25.05.2018

(Web-02) Wywiad Ewy Koszowskiej z Adamem Wajrakiem dla WP Opinie: https://opinie.wp.pl/ adam-wajrak-symbolem-naszego-narodu-jest-dzika-puszcza-6016710193009281a, dostęp 25.05.2018. (Web-o3) Marcin Makowski, Czego ci nie powie Adam Wajrak i inni „obrońcy puszczy” dla WP Opinie: https://opinie.wp.pl/marcin-makowski-czego-ci-nie-powie-adam-wajrak-i-inni-obroncy-puszczy-6016710172992129a, dostęp 25.05.2018 (Web-04) Badanie świadomości i zachowań ekologicznych mieszkańców Polski, Raport PBS przygotowany dla Ministerstwa Środowiska, Sopot 2013, s. 41: Komunikat opublikowany w wersji cyfrowej pod adresem: http://www.mos.gov.pl/g2/ big/2013_12/ee41d9c93bc700729fafo3103120a38c. pdf, dostęp: 25.05.2018.

\title{
Social attitudes to the deforestation of tropical rainforests
}

\begin{abstract}
The article presents the findings of research on attitudes of man toward the problem of destroying of tropical rainforests. The empirical measurement was obtained in the years 2014-2015 from a representative sample of 1,000 inhabitants of Kuyavian-Pomeranian Voivodeship. The respondents were asked to take a stance toward four statements which express approval or disapproval of the clearance of rainforests. Axiologically and normatively, the statements were adjusted either to anthropocentrism or biocentrism, which results from the division accepted in environmental ethics. The results indicate that a substantial majority of the respondents reject individualistic anthropocentrism, according to which rainforest clearance may be justified by the welfare and interests of particular individuals. Simultaneously, they give their full approval for biocentrism statements whose content voices an objection against the destructive impact of humans on the functioning of the tropical jungle. Most respondents allow for the clearance of tropical rainforests only when it serves the interests of the whole society and future generations.
\end{abstract}

\section{Keywords}

forest, environmental sociology, environmental attitudes, anthropocentrism, biocentrism 